\title{
THE NIGHT OF TRAFALGAR
}

I

IN the wild October night-time, when the wind raved round the land, And the Back-sea ${ }^{\mathrm{I}}$ met the Front-sea, and our doors were blocked with sand, And we heard the drub of Dead-man's Bay, where bones of thousands are, We knew not what the day had done for us at Trafalgár.
(All) Had done, Had done,
For us at Trafalgár!

II

'Pull hard, and make the Nothe, or down we go!' one says, says he.

We pulled; and bedtime brought the storm; but snug at home slept we.

Yet all the while our gallants after fighting through the day,

Were beating up and down the dark, sou'-west of Cadiz Bay.

The dark,

The dark,

Sou'-west of Cadiz Bay!

\section{III}

The victors and the vanquished then the storm it tossed and tore, As hard they strove, those worn-out men, upon that surly shore; Dead Nelson and his half-dead crew, his foes from near and far, Were rolled together on the deep that night at Trafalgár!

The deep

The deep,

That night at Trafalgár!

${ }^{I}$ In those days the hind-part of the harbour adjoining this scene was so named, and at high tides the waves washed across the isthmus at a point called 'The Narrows.' 